\title{
Representasi Sosial Masyarakat dalam Film Parasite: Kajian Semiotika Roland Barthes
}

\author{
Regina Dewi Kemalasari, Asma Azizah, Velayeti Nurfitriana Ansas, \\ dan Nuria Haristiani \\ Universitas Pendidikan Indonesia
}

Corresponding authors. reginadewi05@student.upi.edu; asma.azizah@upi.edu; velaansas@upi.edu; nuriaharist@upi.edu

How to cite this article (in APA Style). Kemalasari, R.D., Azizah, A., Ansas, V.N., \& Haristiani, N. (2021). Representasi sosial masyarakat dalam film Parasite: kajian semiotika Roland Barthes. Jurnal Pendidikan Bahasa dan Sastra, 21(1), 123-136. https://doi.org/10.17509/bs_jpbsp.v21i1.36665

History of article. Received: February 2021; Revised: March 2021; Published: April 2021

\begin{abstract}
Abstrak: Penelitian ini bertujuan untuk mengungkap dan mendeksripsikan representasi sosial masyarakat yang tergambar dalam naskah film Parasite karya Bong Joon Ho yang diterbitkan pada tahun 2019 dengan menggunakan pendekatan semiotika lima kode Roland Barthes. Representasi adalah gambaran dari kehidupan nyata masyarakat dalam suatu karya sastra. Metode yang digunakan adalah penelitian deskriptif kualitatif. Teknik analisis data menggunakan model dari Miles \& Huberman yakni, reduksi data, penyajian data, penarikan kesimpulan dan verifikasi. Data yang digunakan berupa leksialeksia yang terdapat dalam naskah film Parasite karya Bong Joon Ho. Berdasarkan hasil penelitian dalam naskah film Parasite terdapat 47 data leksia yang berbeda dan kemudian dikategorikan menjadi lima kode, dengan rincian sebagai berikut: 16 kode hermeneutik, 20 kode semik, 21 kode simbolik, 9 kode proairetik, dan 7 kode kultural. Berdasarkan dari sistem kode tersebut, ditemukan bahwa terdapat bentuk representasi sosial masyarakat dari film Parasite. Adanya kesenjangan sosial diperlihatkan melalui dua keluarga yang memiliki latar belakang berbeda melalui dialog dan narasi pada film. Sistem ekonomi kapitalisme mengakibatkan melebarnya kesenjangan sosial dan mengakibatkan kemiskinan terus terjadi. Selanjutnya adanya perbedaan kelas sosial di dalam struktur sosial masyarakat mengakibatkan adanya konflik sesama kelas dan antar kelas sosial. Di dalam film Parasite, digambarkan bahwa kelas atas memiliki kuasa untuk menjadikan kelas bawah sebagai alat untuk mendapatkan keuntungan sebesar-besarnya.

Kata kunci: film; kelas social; lima kode semiotika; representasi
\end{abstract}

\section{The Social Representation in Film Parasite: Roland Barthes' Semiotics Study}

\begin{abstract}
This study aims to discover and describe the social representation which is illustrated in the script of 'Parasite' film by Bong Joon Ho published in 2019 using the semiotics study of five codes by Roland Barthes. Representation is an illustration of the real-life of society in a literary work. The method used in this study is qualitative descriptive research. The technique of data analysis uses Miles \& Huberman's models, namely, data reduction, data presentation, drawing conclusion, and verification. The data used are in the form of lexia's contained in Bong Joon Ho's 'Parasite' script. The result shows that there are 47 different lexia data and then categorized into five codes, with the following details: 16 hermeneutic codes, 20 semic codes, 21 symbolic codes, 9 proairetic codes, and 7 cultural codes. Based on these code systems, it was found that there is a form of social representation in the film Parasite. The existence of social inequality is shown through two families with different backgrounds through dialogue and narration in the film. The economic system of capitalism causes social inequality and poverty. Furthermore, the existence of differences class in the social structure of society can caused conflicts between social classes. In the film Parasite, it is described that the upper class has the power to make the lower class as a tool to get the maximum benefit.
\end{abstract}

Keywords: film; social class; five semiotic codes; representation 


\section{Pendahuluan}

Bahasa terdiri atas simbol-simbol yang perlu dimaknai agar proses komunikasi berlangsung efektif. Dalam proses komunikasi, bahasa digunakan untuk penyampaian pesan antara manusia, baik secara verbal yang terdiri dari kata-kata maupun secara non verbal. Untuk memahami makna pesan yang disampaikan, maka dibutuhkan sebuah kajian yang mempelajari penggunaan tanda atau simbol tersebut. Sehingga ilmu semiotika diperlukan untuk memahami makna tandatanda atau simbol yang disampaikan baik secara bahasa verbal maupun bahasa non verbal. Menurut (Sobur, 2009) semiotika merupakan suatu ilmu untuk mengkaji tanda. Semiotika berperan untuk mengkaji tanda-tanda yang membentuk suatu kesatuan arti atau makna yang digunakan sehingga penerima pesan dapat memahami makna yang disampaikan.

Ilmu semiotika dipelopori oleh ahli linguistik bernama Ferdinand de Saussure dan ahli filsafat bernama Charles Sanders Peirce. Kedua tokoh tersebut mengembangkan ilmu semiotika secara terpisah. Salah satu tokoh pengembang teori semiotika selanjutnya adalah Roland Barthes. Menurut (Vera, 2014) semiotika Barthes merupakan turunan dari teori semiotika Saussure. Barthes menyempurnakan teori semiotika dengan mengembangan sistem penandaan pada tingkat konotatif. Pada penelitian semiotika dapat digunakan untuk meneliti berbagai macam objek mulai dari iklan, komik, media cetak, sastra, ataupun musik. Salah satu objek yang dapat dianalisis dengan menggunakan kajian semiotika adalah karya sastra. Menurut (Ahyar, 2019) karya sastra dapat digolongkan menjadi dua bentuk yaitu sastra imajinatif dan non imajinatif. Sastra non imajinatif dapat berbentuk esai, jurnal, dan autobiografi. Sedangkan karya sastra non imajinatif berupa puisi, prosa naratif, dan drama. Tetapi dalam penelitian ini, akan memaparkan bentuk lain dari karya sastra imajinatif, yaitu film.
Secara umum film memiliki kesamaan unsur seperti drama yang saling berkaitan satu sama lain, yaitu unsur naratif dan sinematik. Unsur naratif berkaitan dengan aspek cerita atau tema film. Sedangkan unsur sinematik berkaitan dengan aspek teknis produksi film (Dewojati, 2012). Berdasarkan aspek tersebut, penggunaan bahasa dalam sebuah film dapat ditemukan dalam naskah atau teks film Dalam penafsiran makna dalam suatu teks, Barthes mengidentifikasikannya melalui pemenggalan atas teks yang disebut leksia. Menurut (Lantowa, 2017) leksia dapat berupa potongan kata, kelompok kata, beberapa kalimat atau paragraf yang dapat. Setiap leksia dapat mengandung tiga sampai empat makna.

Menurut (Barthes, 1974) di setiap teks setidaknya terdapat lima kode yang di dalamnya terdapat penanda tekstual yang dapat dikelompokkan, yang meliputi:

1. Kode Hermeneutik (HER), kode hermeneutik merupakan kode yang mengandung teka-teki atau tanda tanya yang ditemukan dan dirasakan oleh pembaca

2. Kode Semik (SEM), kode semik atau kode konotatif merupakan penanda yang mengacu pada konotasi dari gambaran-gambaran mengenai kondisi orang, tempat, atau objek dari penanda tertentu.

3. Kode Simbolik (SIM), kode simbolik berkaitan dengan tema dalam arti sebenarnya, sehingga kode ini memiliki hubungan yang erat kode semik atau konotatif, yaitu kode simbolik dapat membawa pembaca untuk memahami simbol-simbol yang terdapat dalam sebuah cerita tema dalam keseluruhan teks.

4. Kode Proaretik atau Aksi (PRO) Kode proairetik atau kode aksi adalah kode yang mengatur alur suatu cerita atau narasi. yaitu serangkaian aksi yang saling berkaitan satu sama lain sehingga membentuk cerita. Dalam sebuah teks dituntut untuk 
memberikan nama yang representatif bagi rangkaian aksi-aksi itu.

5. Kode Kultural (KUL) kode kultural berkaitan dengan berbagai sistem pengetahuan referensi yang mendukung suatu teks.

Berdasarkan hasil penelusuran yang dilakukan oleh peneliti, terdapat penelitian mengenai lima kode semiotika Roland Barthes yang relevan, yaitu penelitian yang dilakukan oleh (Fatimah, 2013) dengan menggunakan lima kode semiotika Roland Barthes. Hasil dari penelitian ini adalah terdapat 17 leksia yang mencerminkan krisis moralitas dalam drama $B A A L$. Selanjutnya penelitian yang dilakukan oleh (Kurniawan, 2017) dengan menggunakan cerita pendek (cerpen) sebagai objek penelitiannya. Hasil dari penelitian ini adalah terdapat 51 leksia yang ditemukan dalam cerpen Laternen. Laternen sendiri memiliki simbol harapan masyarakat Jerman keluar dari keterpurukan pasca Perang Dunia Pertama.

Berbeda dengan penelitian sebelumnya yang sebagian besar mengambil objek berupa novel, cerpen, dan naskah drama. Peneliti akan mengambil objek naskah film Parasite. Pemilihan film sebagai objek dalam penelitian ini dikarenakan film merupakan salah satu media penyampaian pesan terdapat tanda atau simbol yang dibutuhkan penafsiran lebih lanjut untuk memahami setiap makna yang disampaikan. Sebagai penelitian bahasa, maka fokus utama penelitian ini adalah unsur bahasa dalam film Parasite yang dapat ditemukan pada naskah film. Dalam penelitian ini, akan dilakukan penafsiran makna yang sering muncul dalam teks, yaitu representasi sosial masyarakat dengan menggunakan pendekatan lima kode semiotika Roland Barthes.

Dalam menyampaikan pesan atau makna dalam film Parasite karya Bong JoonHo, terdapat representasi mewakili suatu gagasan atau pendapat dalam film tersebut. Representasi menurut (Eriyanto, 2003) berhubungan dengan bagaimana seseorang, kelompok, peristiwa, gagasan, dan kegiatan yang ditampilkan di dalam film. Dalam film Parasite terdapat kritik sosial dan representasi perbedaan kelas antara kelas kaya dan miskin yang terjadi di masyarakat Korea. Tanda-tanda yang memperlihatkan kesenjangan ekonomi dan sosial antara keluarga Park dan Kim digunakan untuk menggambarkan kritik sosial yang disampaikan melalui dialog dalam film tersebut. Berbicara mengenai kelas sosial yang ada dalam kehidupan sosial masyarakat, akan berhubungan dengan pemikiran Marxisme. Dalam pemikiran Marxisme (Risnawati, 2016) menyebutkan pembagian golongan sosial dalam suatu tatanan masyarakat dibagi menjadi tiga kelas, yaitu: 1) kaum buruh yang merupakan kelompok kelas bawah dan hidup dari upah sebagai pekerja, 2) kaum pemilik modal yang hidup dari laba, dan 3) kaum pemilik tanah yang memanfaatkan tanah mereka untuk mendapatkan keuntungan material. Tetapi kenyataanya, golongan tuan pemilik tanah tidak dibicarakan sehingga kelompok tatanan sosial dalam pandangan marxisme menjadi dua, yaitu kelas buruh (proletar) dan kelas majikan (borjuis). (Berry, 2004) mengatakan bahwa kelas borjuis (kelas atas) adalah kelompok yang memilki sarana dan alat produksi yang dalam hal ini adalah perusahaan sebagai modal dalam usaha. Sedangkan kelas ploretar (kelas bawah) adalah kelas yang tidak memiliki sarana dan alat produksi dalam pemenuhan akan kebutuhan ekonominya, sehingga kelas ploretar menjadi pekerja untuk kelas borjuis.

Sehingga pendekatan lima kode semiotika Roland Barthes dilakukan karena dapat menafsirkan setiap makna cerita yang terdapat dalam teks pada naskah dengan lebih mendetail. Kode-kode Semiotika Barthes tersebut yaitu, kode hermeneutik, kode semik, kode simbolik, kode proaretik, dan kode kultural (Sobur, 2009). Dengan memanfaatkan lima kode semiotika tersebut diharapkan dapat memahami pesan atau makna yang disampaikan. Berdasarkan pembahasan di atas, tujuan dari penelitian ini yaitu (1) Untuk mengetahui makna yang terkandung dalam teks film Parasite dengan 
menggunakan pendekatan lima kode semiotika Roland Barthes. (2) Untuk mengetahui representasi sosial masyarakat dalam teks film Parasite dengan menggunakan pendekatan lima kode semiotika Roland Barthes.

\section{Metode}

Berdasarkan (Taylor \& Bodgan, 2016) penelitian kualitatif merupakan prosedur penelitian yang dapat menghasilkan data deskriptif berupa kata-kata, ucapan dan perilaku dari orang-orang yang diamati. Berdasarkan hal tersebut, peneliti menggunakan metode pendekatan deskriptif kualitatif karena data yang diperoleh tidak menggunakan angka ataupun statistik, tetapi hasil penelitian menggunakan uraian dan yang mendeskripsikan representasi sosial masyarakat dalam naskah film Parasite dengan menggunakan kajian sistem kode semiotika Roland Barthes. Dalam penelitian ini data yang digunakan berupa kata, frasa, ataupun kalimat yang mengandung representasi sosial masyarakat dalam naskah film yang terdapat pada buku Parasite Screenplay Book Storyboard Book. Pada langkah pertama, peneliti menentukan masalah dan merumuskan masalah berdasarkan fenomena yang telah ditemukan. Selanjutnya peneliti mengumpulkan datadata pendukung berupa teori-teori yang berkaitan dengan penelitian ini. Selanjutnya peneliti akan membaca dan memahami seluruh isi naskah film yang setelahnya dilakukan penyeleksian satuan leksia yang dapat berupa kata, kalimat, ataupun paragraf berdasarkan lima kode semiotika Roland Barthes. Selanjutnya yaitu membuat laporan penelitian berdasarkan hasil penemuan dan pembahasan yang sudah didapatkan.

\section{Hasil dan Pembahasan}

Dalam penelitian ini, ditemukan terdapat 47 leksia yang mewakili dan mempresentasikan sosial masyarakat pada naskah film tersebut. Selanjutnya leksia tersebut dikategorikan sesuai dengan lima kode semiotika Roland Barthes. Kode-kode semiotik tersebut yaitu, 16 kode hermeneutik, 20 kode semik, 21 kode simbolik, 9 kode proairetik, dan 7 kode kultural. Namun karena keterbatasan ruang dan tujuan dari penelitian, sehingga pada penelitian ini hanya memaparkan analisis leksia yang mewakili dari data-data yang sudah ditemukan.

\section{Leksia Kode Hermeneutik}

1) Leksia (1) / Halaman 11 "기 생 충"

[gi-saeng-chung]

Parasit

(Bong, 2019)

Parasite merupakan judul dalam naskah film, menurut Barthes (1985, hlm. 394) judul dapat berfungsi untuk menandai atau memberi merek pada sebuah teks, sehingga sebuah teks dapat mudah dikenali oleh pembaca. Leksia ini menunjukkan suatu teka-teki yang terdapat dalam kata "기 생충" [gi-saeng-chung] atau parasit dan menimbulkan pertanyaan di benak pembaca akan maksud dari kata dalam teks tersebut yaitu: apa itu 기생충 [gi-saeng-chung] atau parasit? Siapakah parasit dalam naskah film ini? Sehingga leksia ini dapat dikategorikan sebagai kode Hermeneutik kategori 2 yaitu pengusulan masalah. (HER. 1Pengusulan Masalah)

2) Leksia (28) / Halaman 104

$$
\begin{aligned}
& \text { "동익 : 가만 있어봐.. } \\
& \text { (킁킁) 어디서 그... 냄새가 } \\
& \text { 나는데." } \\
& \text { Dong-ik : Kaman iss-eobwa.. } \\
& \text { (keungkeung) eodiseo geu... naemsaega } \\
& \text { naneunde. } \\
& \text { Dong Ik : Tunggu dulu.. } \\
& \text { (mengendus) darimana... bau ini } \\
& \text { datang } \\
& \text { “연교 :뭐?” } \\
& \text { [Yeon Gyo :mwo?] } \\
& \text { Yeon Gyo : apa? } \\
& \text { "동익 : 김기사님 스멜." } \\
& \text { [Dong Ik :Kim-gisanim }
\end{aligned}
$$




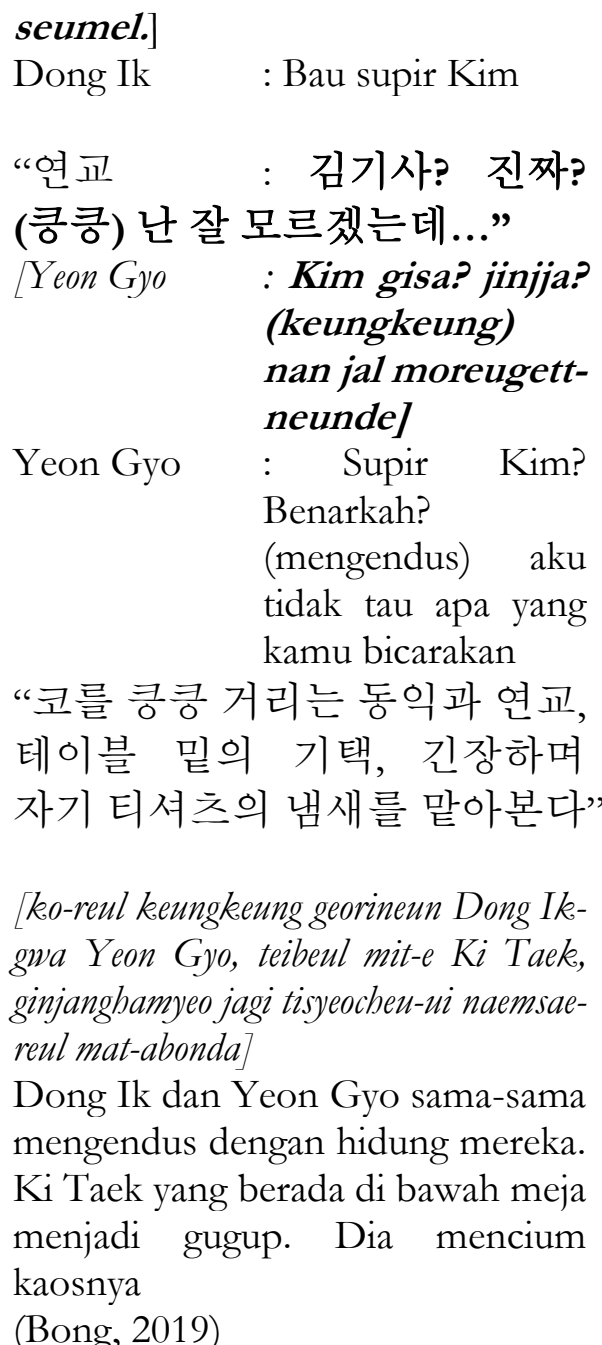

Dong Ik dan Yeon Gyo sedang berada di ruang tamu yang memiliki jendela kaca besar dan mengarah langsung ke arah taman. Mereka sedang mengawasi Da Song yang sedang berkemah di taman tetapi tiba-tiba mereka mencium bau aneh dan Dong Ik mencurigai jika bau itu merupakan bau $\mathrm{Ki}$ Taek. Mereka terus mengendus tetapi tidak dapat memastikan bau Ki Taek berasal dari mana. Pada kenyataannya Ki Taek, Ki Woo, dan Ki Jeong sedang bersembunyi di bawah meja yang berada di dekat Dong Ik dan Yeon Gyo. Pada leksia (28) Yeon Gyo dan Dong Ik sedang membahas mengenai bau dari Ki Taek. Leksia (28) menimbulkan pertanyaan pada mengenai bau seperti apa yang dimiliki oleh Ki Taek? sehingga leksia (28) dapat dikategorikan sebagai Hermeneutik kategori pengusulan masalah (HER 7-Pengusulan Masalah).
Dari hasil temuan, pertanyaanpertanyaan yang muncul dan menjadi tekateki kemudian terjawab, pertama maksud dari Parasite pada judul naskah tidak dapat dijawab secara langsung dan mengharuskan untuk membaca seluruh naskah film agar dapat menarik kesimpulan mengenai Parasite yang dimaksud. Pertanyaan mengenai bau yang dimiliki keluarga $\mathrm{Ki}$ Taek merupakan bau apartement semi basement mereka yang lembap.

\section{Leksia Kode Semik}

Kode semik merupakan penanda bagi dunia konotasi yang memiliki kesan atau nilai rasa tertentu. Terdapat 20 kode semik yang terdapat pada leksia-leksia Berikut adalah beberapa data beserta pembahasannya

1) Leksia (10) / Halaman 22
"기우 : 건강들 하신 데,
일거리가 없으셔들."
Ki Woo: Geongangdeul hasinde,
ilgeoliga eobs-eusyeodeul. $]$
$\mathrm{Ki}$ Woo : Mereka memang sehat tapi mereka tak punya pekerjaan

“민혁 : 기정이도 그냥 집에 있냐? 학원 안가고?”

[Min Hyeok : $\boldsymbol{K i}$ Jeong-ido geunyang jib-e ittya? hak-won an-gago?]

Min Hyeok : Ki Jeong hanya ada di rumah saja? Apa tidak ikut les

\section{"기우 : 학원을...안가는게 아니라 못가는 거지 뭐.” \\ KKi Woo : Hak-won-eul...an- ganeun ge anira motganeun geoji mwo}

Ki Woo : Bukannya dia tidak ingin ikut les, tapi dia tidak bisa ikut (Bong, 2019)

Dengan biaya 학원 [hak-won] yang mahal dan kondisi keluarga $\mathrm{Ki}$ Taek yang pengangguran dan tidak memiliki pekerjaan 
tetap tentunya mereka tidak mampu untuk membiayai $\mathrm{Ki}$ Jeong untuk mengikuti 학원[hak-non]. $\quad \mathrm{Pada}$ kalimat "학원을...안가는게 아니라 못가는 거지 뭐.” [Hak-won-eul...an-ganeun-ge anira motganeun geoji mwo] menggambarkan adanya keingginan $\mathrm{Ki}$ Jeong untuk mengikuti 학원 [bak-won] tetapi karena keluarganya kurang mampu untuk membayar biayanya akhirnya $\mathrm{Ki}$ Jeong mengurungkan niatnya. $\mathrm{Hal}$ ini dikarenakan bagi keluarga Ki Taek yang paling penting adalah mendapatkan pekerjaan untuk mendapatkan uang. Leksia ini mengindikasi adanya ketidakmampuan membiayai kebutuhan sehari-hari. Sehingga leksia tersebut mengandung kode semik (SEM 7-Ketidakmampuan).

2) Leksia (37) / Halaman 116-117

$$
\begin{gathered}
\text { “기정 :아 생일파티 하는 } \\
\text { 건가요?” }
\end{gathered}
$$

[Ki Jeong : Saeng-ilpati haneun geongayo?

Ki Jeong : Oh.. pesta kejutan ulang tahun

$\begin{array}{cl}\text { “연교 : 네. 쌤이 와주시면 } \\ \text { 다송이가 } & \text { 너무너무 } \\ \text { 좋아할텐데” } & \end{array}$

YYeon Gyo :ne. ssaem-i wajusimyeon Da Song-iga neomuneomu jobabaltende]

Yeon Gyo : Iya. Da Song akan sangat senang melihat $\mathrm{Bu}$ Jessica datang

“연교 : 그리구 파스타, 그라탕, 연어스테이크 맛있는거 실컷 드시구 가세요. 나 요리 겁나 잘하는거 알죠? 꼭 오세요."

¿Yeon Gyo :Geurigu paseuta, geulatang, yeon-eoseuteikeu mas-issneungeo silkeos deusigu gaseyo. na yoli geobna jalhaneungeo aljyo? kekog oseyo.]

Yeon Gyo : Lalu kamu bisa menikmati Pasta, Gratin, Steak salmon ... kamu tahu aku koki yang luar biasa, bukan? Kamu harus datang

$$
\begin{aligned}
& \text { "기정 : 아. 네." } \\
& \text { [Ki Jeong : ah. ne.] } \\
& \text { Ki Jeong : Baiklah.. } \\
& \text { "연교 : } 1 \text { 시 까지 오시구요! } \\
& \text { 그리구 오늘 오는거 수업 } \\
& \text { 한 회차로 쳐드릴께요. 유 } \\
& \text { 노우 왓 아이 민? 이따가 } \\
& \text { 뵈요 " }
\end{aligned}
$$

YYeon Gyo :Han-si kkaji osiguyo! geurigu oneul oneungeo sueob han hoecharo chyeodeurilkkeyo. yu nou wat ai min? ittaga boeyo ]

Yeong Gyo : Datanglah paling lambat sampai jam 1 siang! Aku akan menghitungnya sebagai jadwal pelajaran hari ini. You know what I mean?. Sampai nanti!

(Bong, 2019)

Pada potongan Leksia ini menunjukkan kekuasaan Yeon Gyo sebagai seorang majikan. Yeon Gyo menelefon di pagi hari meminta untuk Ki Jeong untuk datang ke pesta ulang tahun Da Song. ia tidak mengetahui apa yang menimpa Ki Jeong dan anggota keluarga lainnya semalam yang mengharuskan seluruh keluarga $\mathrm{Ki}$ Taek mengungsi. Pada pada kutipan "오늘 오는거 수업 한 회차로 쳐드릴께요" menunjukkan jika $\mathrm{Ki}$ Jeong harus datang bukan hanya sebagai tamu tetapi Yeon Gyo menyuruhnya untuk bekerja. Menurut (Magnis-Suseno, 2018) pekerjaan yang melebihi waktu yang diperlukan oleh buruh untuk memenuhi kebutuhan hidupnya merupakan keuntungan bagi pemilik atau majikan. Walaupun $\mathrm{Ki}$ Jeong dan keluarganya terkena musibah ia harus menuruti permintaan Yeon Gyo karena Ki Jeong masih membutuhkan pekerjaan untuk bertahan hidup. Sehingga pada leksia 
ini dapat dicatat sebagai kode semik. (SEM 16-Penguasa)

Jadi berdasarkan data di atas, peneliti menyimpulkan bahwa terdapat uraian hasil penelitian mengenai kode semik, kode semik mengenai makna orang yang berkuasa dan berada di kelas atas dapat melakukan sesuatu pada kelas bawah dan cenderung memaksa seperti yang dilakukan keluarga Dong Ik. Kemudian peneliti menemukan makna dari teks yang menggambarkan sesuatu mengenai kehidupan orang-orang kelas bawah, bagaimana situasi yang mereka jalani membuat orang-orang kelas bawah terpaksa untuk melakukan apa saja supaya mereka tetapi bisa memenuhi kebutuhan hidup mereka.

\section{Leksia Kode Simbolik}

Kode simbolik merupakan penanda teks yang dapat membawa pembaca memasuki dunia lambang-lambang atau tanda-tanda yang memungkinkan adanya satu makna ke makna lainnya. Terdapat 21 kode simbolik yang terdapat pada leksia-leksia, adapun beberapa contoh data leksia simbolik yaitu

1) Leksia (9)/ Halaman 22

“골목과 마트의 허름한 분위기와
안어울리는고급스런
외제스쿠터를등 뒤에 세워놓은
민혁, 마트 앞 플라스틱 테이블에
기우와 마주앉아 과자 안주 등을
펼쳐놓고 소주 한 잔을 하고있다.”
[Golmok-gwa mateu-ui beoreumban
bunwigiwaan-eoullineun gogeubseureon
wijesenkuteo-reuldeung dwie sewonob-eun Min
Hyeok, mateu appeullaseutik teibeul-e KiWoo
majuanj-a gwaja anjudeul-reul pyeolchyeonohgo
soju ban jan-eul hagoiddta].

Min Hyeok memarkirkan skuter mewah buatan luar negeri di belakangnya, yang tidak sesuai dengan suasana gang dan minimarket yang lusuh, Min Hyeok duduk berhadapan dengan Ki Woo di meja plastik yang ada di depan toko, makan makanan ringan sebagai pendamping minum segelas soju. (Bong, 2019)

Setelah mengunjungi apartemen semi basement milik keluarga Kim, Ki Woo dan Min Hyeok berbincang sambil makan makanan ringan dan minum soju. 고급스런 외제스쿠터 [gogeubseureon wijesenkuteo] memiliki arti skuter mewah buatan luar negeri. Skuter tersebut merupakan kendaraan yang digunakan oleh Min Hyeok saat mengunjungi $\mathrm{Ki}$ Woo. Kendaraan impor yang dimiliki Min Hyeok merupakan barang mewah yang dapat dibeli dengan harga mahal, ini menggambarkan jika Min Hyeok berasal dari kalangan keluarga kelas atas. Skuter mewah tersebut diparkirkan oleh Min Hyeok di belakangnya, sangat kontras dengan keadaan gang dan minimarket yang lusuh. Suasana lusuh tersebut menggambarkan situasi jika orangorang yang tinggal di lingkungan tersebut memiliki perekonomian yang rendah. Sehingga skuter impor milik Min Hyeok tampak mencolok di lingkungan tersebut. Pada Leksia di atas terlihat adanya kesenjangan sosial, yaitu antara barang mewah dan lingkungan yang lusuh. Sehingga pada leksia ini dapat dicatat kode simbolik (SIM 6-Kesenjangan Sosial).

2) Leksia (26) / halaman 94

“그와 동시에 문광이 부억을 향해 계단을 달려 올라온다! 짜파구리 냄비를 한 손에 든 채로, 지하계단 입구로 몸을 돌리는 충숙, 큰 발을 번쩍 들어 문광의 얼굴을 밀어버린다! 계단 아래로 굴러 떨어지는 문광. 계단 중간에 머리를 쿵! 찧는다. 강한 뇌진탕! 쫓아오던 기택, 화들짝 놀란다. 지친 얼굴로 부억에 들어온 연교, 간발의 차로 충숙의 발차기를 보지 못한 채, 식탁에 앉는다." [geuwa dongsi-e Mun Gwang-i bueok-eul hyanghae gyedan-eul dallyeo ollaonda! jjapaguri 
naembileul han son-e deun chaero, jihagyedan ibguro momeul dollineun Chung Sug, keun bal-eul beonjjeog deul-eo Mun Gwang-ui eolgul-eul mileobeolinda! gyedan alaelo gulleo tteol-eojineun Mun Gwang. Gyedan jung-gan-e meolileul kung! jjitneunda. Ganghan noejintang! jjoch-aodeon $\mathrm{Ki}$ Taek, bwadeuljjak nollanda. jichin eolgullo bueok-e deul-eo-on Yeon Gyo, ganbal-ui charo Chung Suk-ui balchagi-reul boji mothan chae, sigtak-e an-janeunda.]

Chung Suk melihat Mun-Kwang berlari dari ruang bawah tanah penyimpanan. Chung Sok membalikkan tubuhnya ke arah pintu masuk ruang bawah tanah dengan panci jjapaguri di satu tangannya. Dia mengangkat kakinya yang besar dan mendorong wajah Mun Gwang! Mun Gwang terjatuh ke bawah tangga dan kepalanya membanting di salah satu anak tangga. Sepertinya ia mengalami geger otak yang kuat. Ki Taek yang mengejarnya tiba-tiba terkejut melihat situasi itu. Yeon Gyo memasuki dapur dengan wajah Lelah. Dia duduk di meja tanpa melihat tendangan Chung Suk. (Bong, 2019)

Menurut Magnuz Suseno (2018, hlm. 123) kelas sosial bawah memiliki kepentingan terhadap perubahan, karena mereka kaum tertindas mengakibatkan setiap perubahan dapat mempengaruhi keadaan mereka. Pada kutipan kalimat “지친 얼굴로 부억에 들어온 연교, 간발의 차로 충숙의 발차기를 보지 못한 채, 식탁에 앉는다" [jichin eolgullo bueok-e deul-eo-on Yeon Gyo, ganbal-ui charo Chung Suk-ui balchagi-reul boji mothan chae, sigtak-e an-janeunda]. Menunjukkan bahwa Yeon Gyo tidak menyadari bahwa di rumahnya terdapat konflik sesama kelas sosial bawah karena konflik yang terjadi pada keluarga Ki Taek dan keluarga Mun Gwang mengisyaratkan jika perjuangan kelas hanya terjadi pada kelas sosial bawah. Kelas sosial atas seperti keluarga Dong Ik tidak akan memedulikan dan terpengaruh oleh konflik yang terjadi pada sesama kelas sosial bawah kecuali hal itu mengganggu kedudukan mereka dari kelas atas seperti pada leksia (13). Dengan demikian leksia ini dapat dicatat sebagai kode simbolik (SIM 13-Tidak Peduli)

3) Leksia (32) / Halaman 105

"마지못해 듣고있는 테이블 아래쪽 사람들. 굳은 얼굴의 기택, 어둠 속에서 침묵을 유지한다."

[Majimothae deudgoitt-neun teibeul araejjog saramdeul. Gud-eun eolgului Ki Taek, eodum sok-eseo chimmug-eul yujihanda

Orang-orang yang ada di bawah meja itu mendengarkannya dengan terpaksa. $\mathrm{Ki}$ Taek dengan wajah tegangnya, diam di dalam kegelapan.

(Bong, 2019)

Ki Taek mendengar semua keluhan dan hinaan yang diucapkan oleh Dong Ik mengenai bau yang dimilikinya sangat mengganggu. Tempat di mana keluarga Dong Ik dan Ki Taek berada menyimbolkan status sosial mereka. Dong Ik dan Yeon Gyo berada di atas sofa sedangkan Ki Taek berada di bawah meja menunjukkan bahwa keluarga Dong Ik berasal dari kelas atas sedangkan Ki Taek dan keluarga berasal dari status sosial bawah. $\mathrm{Ki}$ Taek dan anak-anaknya hanya bisa bersembunyi seperti kecoa yang berada di rumahnya. Menurut (Magnis-Suseno, 2018) kelas bawah harus tunduk terhadap kekuasaan kelas atas. Hal ini juga diperlihatkan pada $\mathrm{Ki}$ Taek dan kedua anaknya yang tidak bisa berbuat apa-apa saat mendengar hinaan tersebut karena mereka harus menempatkan posisinya sebagai pekerja selain itu mereka juga sedang bersembunyi sehingga tidak bisa menentang ataupun melawan Dong Ik sebagai pemilik kekuasaan. Sehingga leksia (32) dapat dicatat sebagai kode simbolik. (SIM 15-Diam)

Pada kode-kode simbolik yang muncul 
di naskah film Parasite peneliti menemukan kode simbolik seperti: bau, apartement semi basement, dan tempat gelap ini menyimbolkan kemiskinan orang-orang yang berasal dari kalangan bawah. Kendaraan mewah yang ada di lingkungan kumuh juga disimbolkan sebagai kesenjangan sosial antara masyarakat kelas atas dan kelas bawah hal ini mengartikan jika kesenjangan sosial, seperti yang terjadi pada leksia (9). Bau disimbolkan sebagai bau basement atau bau kemiskinan yang selalu berdampingan di antara orang-orang kelas bawah dan kelas atas. Lalu hujan juga dapat disimbolkan sebagai suatu berkah dan bencana, seperti pada leksia (35) dan (36) hujan menjadi berkah bagi orang-orang kalangan atas karena dapat mempelancar urusan mereka sedangkan bagi orang-orang kalangan bawah hujan menjadi suatu bencana karena tempat tinggal mereka terkena banjir. Sedangkan kegelapan di simbolkan sebagai tidak adanya harapan hidup seperti pada leksia (44), (45).

\section{Leksia Kode Proaeretik atau Aksi}

Kode proaeretik atau aksi adalah serangkaian aksi-aksi yang saling berkaitan antara satu sama lain. Terdapat 9 kode proairetik yang terdapat pada leksia-leksia. Adapun contoh leksia yang mengandung kode proaeretik

1) Leksia (12) / Halaman 25

“행인은 없고 담벼락은 높은 고급주택가의 언덕길. 가방을 멘 기우가 외롭게 걸어가고 있다. 스마트폰 지도를 보면서 주위를 두리번 거리는 기우, 발걸음을 재촉한다."

[Haeng-in-eun eobgo dambyeorageun nop-eun gogeubjutaekga-ui eondeok-gil. Kabang-eul men Ki Wooga wirobge geol-eogago iddta. seumateupon jido-reul bomyeonseo juwi-reul dulibeon geolineun $\mathrm{Ki}$ Woo, balgeol-eum-eul jaechokbanda]

Tidak ada pejalan kaki di jalan berbukit perumahan kelas atas dengan pagar tinggi. Ki Woo berjalan sendirian dengan tasnya yang terikat di punggungnya sambil melihat peta di ponselnya, ia melangkah dengan tergesa-gesa (Bong, 2019)

Pada leksia di atas terdapat penggambaran aksi yang dilakukan oleh Ki Woo, yang kemudian membuka petualangan dalam cerita pada naskah film Parasite. Ia pergi ke perumahan orang kaya untuk untuk menggantikan Min Hyeok menjadi tutor bahasa Inggris di keluarga Dong Ik. Leksia ini juga menjadi gambaran penting dari seluruh aksi yang ada di dalam naskah karena aksi yang ada dalam naskah. Hal ini dikarenakan melangkah yang merupakan aksi pada leksia ini merupakan titik awal untuk melangkah dari perubahan kehidupan Ki Woo dan keluarga menjadi lebih baik, walaupun ia menggunakan dokumen-dokumen palsu untuk menipu menjadi tutor bahasa inggris. (PRO 2Melangkah)

2) Leksia (43) / halaman 131-132

$$
\begin{aligned}
& \text { “연이어 근세의 몸뚱아리를 } \\
& \text { 들춰올려 마침내 벤츠 키를 } \\
& \text { 찾아내는 동익. 그 순간 근세의 } \\
& \text { 몸에서 심한 악취를 느꼈는지 } \\
& \text { 눈을 찌푸리며 코를 막는다. } \\
& \text { 동익의 그 순간이 기택의 눈을 } \\
& \text { 찌른다." }
\end{aligned}
$$

[Yeon-ieo Geunse-ui momttung-arireul deulchwoollyeo machimnae benchen ki-reul chaj-anaeneun Dong Ik. Geu sun-gan Geunse-ui mom-eseo simhan akchwi-reul neukkyeott-neunji nun-eul jjipurimyeo ko-reul mangneunda. Dong Ik-ui geu sungan-i Ki Taek-ui nun-eul jjireunda] Dong Ik akhirnya menemukan kunci Benz setelah mengangkat tubuh Geun Se terus menerus. Pada saat itu, dia mengerutkan kening dan menutup 
hidungnya saat mencium bau busuk dari tubuh Geun Se. Momen Dong Ik itu terlihat oleh mata $\mathrm{Ki}$ Taek.

“순간, 눈빛이 확 바뀌는 기택. 잔디밭에 뒹구는 인디언 도끼를 다시 움켜 쥐고, 동익의 뒤를 성큼성큼 쫓아간다. 동익, 발소리에 힐끔 뒤를 돌아보는데. 휘익 허공을 가르는 기택의 도끼날. 동익의 목과 어깨 사이를 퍽-찍는다."

[Sungan, nunbich-i bwak bakkwineun Ki Taek. Jandibat-e dwing-guneun indieon dokki-reul dasi umkyeo jwigo, Dong Ik-ui dwi-reul seongkeum-seongkeum jjochaganda. Dong Ik, balsori-e bilkkeum dwireul dol-aboneunde. hwiik heogong-eul gareuneun Ki Taek-ui dokkinal. Dong Ik-ui mok-gwa eokkae saireul peok-jjigneunda]

Saat itu sinar mata Ki Taek berubah seketika. Ki Taek mengambil kapak Indian yang tergeletak di atas rumput, berjalan dengan langkah lebarnya lalu mengejar Dong Ik. Dong Ik berbalik saa mendengar langkah kaki Ki Taek, tetapi Ki Taek mengayunkan kapaknya di udara dan menusuk tepat di antara leher dan bahu Dong-Ik. (Bong, 2019)

Penusukan $\mathrm{Ki}$ Jeong dan perkelahian antara Chung Suk dan Geun Se mengakibatkan kekacauan yang tidak terkendali. Tamu-tamu yang berada di sana sibuk menyelamatkan dirinya masingmasing. Ki Taek kebingungan atas situasi tersebut dan tidak bisa berbuat apa-apa, ia hanya melemparkan kunci mobil milik Dong Ik. Permasalahan bau kembali dimunculkan pada leksia (43), saat kunci mobil Dong Ik tertindih tubuh Geun Se yang terjatuh. Dong Ik mengangkat tubuh Geun Se dan menutup hidungnya ketika ia mencium bau busuk dari Geun Se. Ki Taek melihat tindakan Dong Ik yang menutup hidungnya. Tindakan Dong Ik yang dilihat oleh Ki Taek seolah-olah menghina dirinya juga, dikarenakan sebelumnya Dong Ik mengeluh terhadap bau $\mathrm{Ki}$ Taek yang seperti lap kotor yang direbus. Akibatnya, Ki Taek tanpa sadar mengambil kapak yang tergeletak dan menancapkannya di antara leher dan bahu Dong Ik. Adanya aksi yang dilakukan Ki Taek dan apa yang ia perbuat mengindikasikan adanya kode aksi proairetik. Aksi yang dilakukan $\mathrm{Ki}$ Taek termasuk bentuk perlawanan dari kelas bawah yang tertindas atas perlakuan kelas atas. Sehingga pada leksia ini dapat dikategorikan sebagai kode proaeretik. (PRO 7-Melawan)

Penggambaran kode aksi yang membentuk keseluruhan cerita dari naskah ini dicerminkan oleh Min Hyeok yang menawari pekerjaan sebagai tutor untuk keluarga Dong Ik seperti pada leksia. Dari aksi yang dilakukan oleh Min Hyeok pun membentuk ke cerita selanjutnya. Ki Woo yang mulai bekerja sebagai tutor bahasa Inggris sampai seluruh keluarganya perlahan bekerja di rumah Dong Ik. Sampai kepada aksi yang mengakibatkan konflik antar sesama kelas bawah dan kelas atas yang mengakibatkan korban jiwa.

\section{Leksia Kode Kultural}

Kode kultural merupakan penandapenanda yang merujuk pada referensi atau pengetahuan umum yang dapat mendukung isi teks. Terdapat 7 kode kultural. Adapun contoh leksia yang mengandung kode kultural yaitu:

1) Leksia (18) / Halaman 66

$$
\begin{gathered}
\text { “기택 : (삿포로 캔 들며) 자자자 } \\
\text { 아무튼! 우리가 지금 이런 } \\
\text { 고민을 하는 것 자체가, 이 } \\
\text { 얼마나 행복한 고민이냐 이 } \\
\text { 말이지. 경비원 한 명만 } \\
\text { 뽑아도 } 4 \text { 년제 대졸자가 } \\
\text { 오백명씩 몰려드는 이 } \\
\text { 시대에... } \\
\text { (감격) }
\end{gathered}
$$


우리는!식구가! 전원취업!”

KKi Taek : (sapporoo kaen deulmyeo) jajaja amuteun! uriga jigeum ireon gomin-eul baneun geo jachega, $i$ eolmana baengboghan gomin-inya $i$ mal-iji. Gyeongbiwon han

myeongman

4nyeonje

obaegmyeongssig

mollyeodeu-neun $i$ sidae... (gamgyeog) urineun!sikguga! jeonwonchwieob!]

Ki Taek : (Mengambil kaleng Sapporo) sudah lupakan itu! Bukankah kita ini beruntung, mengapa mengkhawatirkan hal-hal semacam ini, Di zaman ini, di mana 500 lulusan perguruan tinggi berbondong-bondong satu sama lain meski hanya memilih untuk jadi satpam (emosional) Kita! Semua anggota keluarga! Semua dipekerjakan! (Bong Joon Ho, 2019, hlm. 66)

Pada leksia ini menunjukkan untuk mendapatkan pekerjaan yang layak seseorang harus bersaing dengan 500 orang lainnya untuk mendapatkan pekerjaan walaupun sebagai satpam. Berdasarkan data statistik Korea yang dilansir dari PulseNews (2020) jumlah pengangguran yang ada di Korea dengan rentang usia 15 -29 tahun mencapai 1,66 juta naik 120.000 dari tahun 2019. Hal ini menyebabkan lapangan pekerjaan yang ada tidak sesuai dengan para pencari kerja mengakibatkan banyak pengangguran. Sedangkan pada leksia ini keluarga Ki Taek sangat bersyukur karena semua anggota keluarga berkerja walaupun mereka bukan seorang lulusan sarjana tetapi pada kenyataanya mereka harus menipu dan berpura-pura demi mendapatkan pekerjaan yang sekarang. Leksia yang mengandung informasi seperti ini dapat dikategorikan sebagai kode kultural. (KUL 5Pengangguran) Representasi Sosial Masyarakat
Dari hasil analisis yang telah dilakukan peneliti pada naskah film Parasite dengan menggunakan kajian lima kode semiotika Roland Barthes, yaitu:

\section{1) Kesenjangan Sosial}

Perbedaan kelas sosial yang mereka miliki juga mengakibatkan perbedaan gaya hidup yang mereka jalani. Keluarga Ki Taek tinggal di apartemen semi basement yang ada di lingkungan kumuh. Kehidupan yang dijalani oleh keluarga $\mathrm{Ki}$ Taek serba kekurangan, mereka sendiri tidak mempunyai pekerjaan tetap dan hanya bekerja sebagai pelipat kardus pizza. Berbeda dengan kelas bawah yang identik dengan permasalahan ekonomi. Keluarga Dong Ik mewakili keluarga kelas atas lain yang hidup dengan tenang dan berlimpah harta tanpa mempunyai masalah-masalah ekonomi yang biasa dialai oleh keluarga dari kelas bawah. Keluarga Park Dong Ik tinggal di lingkungan perumahan elit yang jauh dari perkotaan dan terletak di atas bukit. Penggambaran yang dilakukan oleh antara keluarga $\mathrm{Ki}$ Taek dan Dong ik mengkontradiksikan kedua kelas masyarakat tersebut dengan sangat berbeda.

\section{2) Konflik Sosial}

Dalam naskah ini tidak diceritakan adanya perjuangan kelas bawah untuk melawan kelas atas, yang ada hanya kelompok masyarakat kelas bawah yang saling berkonflik satu sama lain untuk memperebutkan kepentingan mereka. Seperti pada leksia (26) terjadi konflik antara keluarga Mun Gwang dan Ki Taek. Keluarga $\mathrm{Ki}$ Taek sudah lama menjadi pengangguran sedangkan keluarga Mun Gwang harus membayar semua hutanghutangnya, mereka sama-sama kesulitan mendapatkan pekerjaan selain bekerja di rumah Dong Ik. Perebutan posisi pekerja ini lah yang membuat konflik dua keluarga yang berasal dari kelas bawah.

Selanjutnya, konflik terjadi antara kelas atas dan kelas bawah. Kelas atas sebagai pihak yang mendominasi dan berkuasa akan 
menindas kelas bawah. Hal ini juga terlihat pada leksia (29) saat Dong Ik menghina Ki Taek dengan menyamakannya seperti lap kotor yang direbus atau lobak tua yang kering. Perlawanan dilakukan saat Dong Ik mengangkat tubuh Geun Se karena ia menindih kunci mobilnya dan menutup hidung karena bau busuk tercium dari Geun Se. Ki Taek yang tersinggung dan melihat kejadian tersebut lalu menancapkan kapak pada dada Dong Ik. Perlawanan yang dilakukan $\mathrm{Ki}$ Taek tidak berhasil karena bukannya mengubah nasibnya tetapi ia memperburuk kondisinya.

\section{3) Penguasaan Struktur Sosial}

Pada naskah film Parasite, terdapat unsur kelompok yang dibentuk secara vertikal. Bentuk tersebut dapat dilihat dengan adanya dua keluarga yang berbeda satu sama lain. Kedua bentuk kelompok masyarakat tersebut tidak berjalan secara selaras dikarenakan adanya faktor mendominasi dan didominasi. Keluarga Dong Ik merupakan pemilik modal yang membuatnya memiliki kekuasaan, sedangkan keluarga $\mathrm{Ki}$ Taek yang berasal dari kelas sosial bawah tidak memiliki hak tersebut dan hanya bisa menuruti apa yang diperintahkan majikan karena membutuhkan uang untuk membiayai kebutuhan mereka.

\section{4) Masalah Kemiskinan}

Dengan adanya sistem kapitalisme, pemiliki modal mengambil untung sebanyak-banyaknya yang menimbulkan kesenjangan sosial dan mengakibatkan kemiskinan di masyarakat. Pada naskah film Parasite kemiskinan digambarkan melalui keluarga Ki Taek dan Mun Gwang.

Masalah kemiskinan yang dialami oleh kaum buruh dideskripsikan oleh keluarga $\mathrm{Ki}$ Taek dengan cara yang alamiah dan cenderung menampilkan sisi liarnya dengan menghalalkan mencoba berbagai cara agar keluar dari kemiskinan. Kemiskinan yang terjadi menyebabkan keluarga Ki Taek tidak bisa memenuhi kebutuhan hidup seharihari mereka dengan layak karena kondisi yang serba sangat kekurangan. Seperti yang dilakukan oleh $\mathrm{Ki}$ Jeong yang mencuri di minimarket dan mewajarkan perilakunya tersebut karena ia merupakan 불우 이웃 [bulu iut] yaitu orang-orang yang membutuhkan bantuan karena ia tidak mampu secara sosial atau ekonomi seperti yang dijelaskan leksia (6).

Pada akhirnya, naskah film Parasite ini dengan jelas menunjukan kritik terhadap kondisi sosial masyarakat yang terjadi. Keseluruhan permasalahan yang ditampilkan merepresentasikan kondisi sosial masyarakat yang terjadi di Korea saat ini. Bagaimana sistem ekonomi kapitalisme mengakibatkan melebarnya kesenjangan sosial yang mengakibatkan kemiskinan terus terjadi. Kelas atas sebagai pemilik kuasa penuh untuk menjalankan sistem perekonomian, sedangkan kelas bawah hanya dijadikan sebagai alat untuk mendapatkan keuntungan sebesar-besarnya. Yang pada akhirnya menjadikan seseorang memiliki status sosial yang berbeda di masyarakat, dan membuat orang kaya semakin kaya dan orang miskin akan terus berada dalam keterpurukan.

\section{Simpulan}

Berdasarkan hasil penelitian dan pembahasan yang telah diuraikan terdapat simpulan dari penelitian yang berjudul "Representasi Sosial Masyarakat Dalam Film Parasite: Kajian Semiotika Roland Barthes". Simpulan tersebut sebagai berikut.

Penelitian terhadap naskah film Parasite karya Bong Joon Ho dengan menggunakan kajian semiotika Roland Barthes menunjukkan bahwa terdapat 47 leksia, leksia-leksia tersebut dikategorikan sesuai dengan lima kode semiotika yang terdiri dari 16 kode hermeneutik, 20 kode semik, 21 kode simbolik, 9 kode proairetik, dan 7 kode kultural.

Hasil dari penelitian menunjukkan bahwa pada naskah film Parasite adalah teks yang mengkritik terhadap realitas yang ada dalam kondisi sosial masyarakat Korea. Hal ini direpresentasikan dengan adanya konflik sesama kelas dan konflik antar kelas yang 
berujung dengan adanya korban jiwa. Konflik terjadi di antara sesama kelas bawah disebabkan karena saling memperebutkan posisi pekerjaan mereka. Sedangkan konflik yang terjadi antarkelas melalui keluarga $\mathrm{Ki}$ Taek dan Dong Ik disebaban karena perlakuan kelas atas pada kelas bawah sudah bertindak di luar batas kewajaran. Sehingga Ki Taek memutuskan melakukan perlawanan dengan tindakan kekerasan yang mengakibatkan Dong Ik menjadi korban.

Adanya penguasaan struktur sosial di masyarakat menyebabkan terjadinya pihak yang didominasi dan mendominasi. Kelas atas yang memiliki kekuasaan membuat mereka dapat mendominasi, sedangkan kelas sosial bawah menjadi pihak yang dikuasai oleh kelas atas

Pada naskah film ini juga mengkritik sistem perekonomian kapitalisme yang terjadi sehingga menimbulkan masalah kemiskinan. Kemiskinan yang terjadi mengakibatkan ketidaksejahteraan kelas bawah.

\section{Daftar Rujukan}

Ahyar, J. (2019). Apa Itu Sastra. Yogyakarta: Deepublish.

Barthes, R. (1974). S/Z Roland Barthes. (R. Miller, Trans.) New York: Farrar, Straus \& Giroux.

Berry, D. (2004). Pokok-Pokok Pikiran dalam Sosiologi. Jakarta: PT Raja Grafindo Persada.

Bong, Joon Ho., Han, Ji Won. (2019). 기생충 각본집 \& 스토리보드북 세트. 서울: 교보문고.

Dewojati, C. (2012). Drama: sejarah, teori dan penerapannya. Yogyakarta: Javakarsa Media.

Eriyanto. (2003). Analisis W acana Pengantar Analisi Teks Media. Yogyakarta: LKIS Yogyakarta.

Fatimah, N. (2013). Krisis Moralitas Dalam Drama baal Karya Bertolt Brecht: Analisis Lima Kode Semiotika Roland
Barthes. Yogyakarta: Universitas Negeri Yogyakarta.

Kurniawan, R. (2017). Telaah Makna Kuragesichte Laternen Karya Marie Luise Kaschnitz. Melalui Analisis Lima Kode Semiotik Roland Barthes. Yogyakarta: Universitas Negeri Yogyakarta.

Lantowa, J., Marahayu, N. M., \& Khairussibyan, M. (2017). Semiotika: Teori, Metode, dan Penerapannya dalam Penelitian Sastra. Yogyakarta: Deepublish.

Magnis-Suseno, F. (2018). Pemikiran Karl Marx: dari sosialisme utopis ke perselisiban revisionisme. Jakarta: Gramedia Pustaka Utama.

Risnawati, R., Anshari, A., \& Abidin, A (2016). Pertentangan Dan Kesadaran Kelas Dalam Novel Bumi Manusia Karya Pramoedya Ananta Toer (Pendekatan Teori Marxis). RETORIKA: Jurnal Bahasa, Sastra, dan Pengajarannya, 9(1), 68-79. doi:https://doi.org/10.26858/reto rika.v9i1.3795

Sobur, A. (2009). Semiotika Komunikasi. Bandung: Remaja Rosdakarya.

Taylor, S. J., \& Bodgan, R. (2016). Introduction to Qualitative Research Methods: A Guidebook and Resource. New Jersey: John Wiley \& Sons.

Vera, N. (2014). Semiotika dalam Riset Komunikasi. Bogor: Ghalia Indonesia. 
Jurnal Pendidikan Bahasa dan Sastra, Volume 21, Nomor 1, April 2021, pp. 123-136 